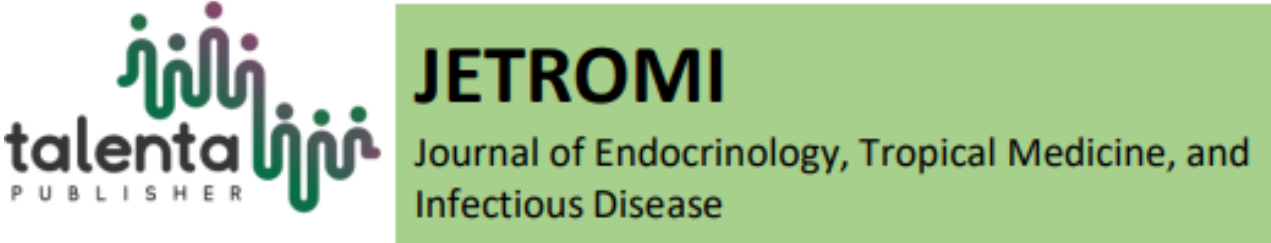

\title{
Immature Platelet Fraction in Thrombocytopenic Patients
}

\author{
Dwita Margareth Sinaga $^{1^{*}}$, Dairion Gatot ${ }^{2}$ \\ ${ }^{1}$ Faculty of Medicine, University of Sumatera Utara, Medan, Indonesia \\ ${ }^{2}$ Division of Hematology and Medical Oncology, Department of Internal Medicine, Faculty of Medicine, \\ University of Sumatera Utara/Haji Adam Malik General Hospital, Medan, Indonesia
}

\begin{abstract}
.
Background. Bone marrow puncture (BMP) is usually performed to identify thrombopoiesis activity and is still the gold standard to determine the etiology of thrombocytopenia. This diagnostic test is invasive hence it may cause discomfort to the patient.

Methode. This research was a cross-sectional descriptive observational study aimed to evaluate immature platelet fraction (IPF) value in thrombocytopenic inpatients in the Department of Internal Medicine, Haji Adam Malik Hospital Medan.

Result. Of 83 people were recruited, there were 48 (57.83\%) female and 35 (42.16\%). The male and the median age was 44.41 years.

IPF values ranged $0.5-59.6 \%$ using Sysmex XN1000 (reference range 1-4.8\%). In the peripheral group, the majority of the patients $(n=24)$ showed increased IPF, oddly, it was also found increased in the central group ( $\mathrm{n}=25)$. IPF was found the highest in ITP patients (median 33.2\%) and the lowest in aplastic anemia patients (median 2.6\%).

Conclusion. Regardless, IPF is a promising tool in the diagnosis of thrombocytopenia, and it should be taken into consideration of routine laboratory examination in thrombocytopenic patients
\end{abstract}

Keyword: IPF, Thrombopoiesis, Platelet, Thrombocytopenia.

\begin{abstract}
Abstrak.
Latar belakang. Bone marrow puncture (BMP) biasanya dilakukan untuk mengidentifikasi aktivitas trombopoiesis dan masih standar emas untuk menentukan etiologi trombositopenia.
\end{abstract}

${ }^{*}$ Corresponding author at: Faculty of Medicine, Universitas Sumatera Utara, Medan, Indonesia

E-mail address: dwitamargs@gmail.com

Copyright (C 2021 Published by Talenta Publisher, ISSN: 2686-0872 e-ISSN: 2686-0856

DOI: https://doi.org/ 10.32734/jetromi.v3i4.7464

Journal Homepage: https://jetromi.usu.ac.id

Attribution-NonCommercial-ShareAlike 4.0 International 
Tes diagnostik ini bersifat invasif sehingga dapat menyebabkan ketidaknyamanan pada pasien.

Metode. Penelitian ini merupakan studi observasional deskriptif cross-sectional yang bertujuan untuk mengevaluasi nilai fraksi trombosit belum matang (IPF) pada pasien rawat inap trombocytopenic di Departemen Penyakit Dalam, RUMAH Sakit Haji Adam Malik Medan.

Hasil. Dari 83 orang yang direkrut, ada 48 (57,83\%) perempuan dan 35 (42,16\%). lakilaki dan usia rata-rata adalah 44,41 tahun.

Nilai IPF berkisar 0,5-59,6\% menggunakan Sysmex XN1000 (rentang referensi 1-4,8\%). Pada kelompok perifer, mayoritas pasien $(n=24)$ menunjukkan peningkatan IPF, anehnya, itu juga ditemukan meningkat pada kelompok sentral $(n=25)$. IPF ditemukan tertinggi pada pasien ITP (median 33,2\%) dan terendah pada pasien anemia aplastik (median 2,6\%).

Kesimpulan. Terlepas dari itu, IPF adalah alat yang menjanjikan dalam diagnosis trombositopenia, dan harus dipertimbangkan pemeriksaan laboratorium rutin pada pasien trombositopenik.

Kata kunci: IPF, Thrombopoiesis, Platelet, Trombositopenia.

Received 22 October 2021 | Revised 30 November 2021 | Accepted 30 November 2021

\section{Introduction}

Thrombocytopenia is a common hematological abnormality. There are many etiologies of thrombocytopenia. Generally, it is divided into reduced thrombopoiesis (central) and increased platelet destruction (peripheral). Bone marrow puncture (BMP), is usually performed to identify thrombopoiesis activity and is still the gold standard to determine the etiology of thrombocytopenia. However, this diagnostic test is very invasive hence it may cause discomfort to the patient. One noninvasive test to help determine the etiology of thrombocytopenia is by measuring immature platelet fraction (IPF). IPF reflects the value of reticulated platelets, newly released platelets in peripheral blood. They can be distinguished from mature platelets by their RNA content and their larger size[1]. IPF has been reported significantly higher in cases of increased platelet consumption [2] and reduced in bone marrow failure cases, highlighting the thrombopoiesis activity in the bone marrow.[3] By understanding the value, clinicians can use it in determining whether or not the invasive examination is needed and more importantly avoiding unnecessary platelet transfusion.

\section{Methods}

This study used a descriptive, cross-sectional study design, conducted in Haji Adam Malik Hospital, Medan. Thrombocytopenic inpatients in the Department of Internal Medicine were enrolled in this study from June to August 2019. The data obtained were the sociodemographic information, diagnosis of the patients, platelet count, and bleeding manifestation. Complete blood 
count and IPF measurement were done in the Laboratory of Clinical Pathology, Haji Adam Malik Hospital, Medan. The study was conducted with the approval of the Ethical Committee on Health Research, Medical Faculty of Universitas Sumatera Utara/H.Adam Malik General Hospital Number 88/TGL/KEPK FK USU-RSUP HAM/2019.

\section{Results}

The study included 83 inpatients, 48 were female (57.83\%) and 35 were male $(42.16 \%)$ and median age was 44.41 years. Thrombocytopenia was peripheral in 29 patients $(34.93 \%)$ and central in 54 patients $(65.06 \%)$. In the peripheral group, etiology of thrombocytopenia were viral infection ( $n=12 / 14.45 \%)$, idiopathic thrombocytopenic purpura/ITP $(n=9 / 10.84 \%)$, consumption coagulopathy $(n=6 / 7.22 \%)$ and sepsis $(n=2 / 2.40 \%)$. In the central group, diagnoses were myelodisplastic syndrome/MDS $(\mathrm{n}=17 / 20.48 \%)$, aplastic anemia $(\mathrm{n}=13 / 15.66 \%)$, acute lymphoblastic leukemia/ALL ( $\mathrm{n}=10 / 12,04 \%)$, acute myeloid leukemia/AML ( $\mathrm{n}=9 / 10.84 \%)$, chronic myeloid leukemia/CML $(n=3 / 3.61 \%)$ and multiple myeloma $(n=2 / 2.40 \%)$.

Table 1, shows bleeding manifestation in patients based on the platelet count. Bleeding occurred in 37 patients $(44.57 \%)$ and majority of the patients $(n=33)$ has platelet count $<50.000 / \mathrm{mm} 3$ with hematoma $(n=10)$, gum bleeding $(n=8)$ and petechiae $(n=8)$ as most common bleeding manifestations.

Table 1 Clinical characteristics

\begin{tabular}{lcccc}
\hline Bleeding manifestations & $<50.000 / \mathrm{mm}^{3}$ & $50.000-99.000 / \mathrm{mm}^{3}$ & $100.000-150.000 / \mathrm{mm}^{3}$ & Total \\
\hline Bleeding & 8 & 2 & 0 & \\
Hematoma & 8 & 0 & 0 & 8 \\
Gum bleeding & 8 & 0 & 0 & 8 \\
Ptechiae & 2 & 0 & 1 & 3 \\
Subconjunctival & 2 & 0 & 0 & 2 \\
haemorrhage & 1 & 1 & 0 & 2 \\
Melena & 1 & 0 & 0 & 11 \\
Menorrhagia & 1 & 0 & 0 & 11 \\
Epistaxis & 1 & 0 & 0 & 1 \\
Vaginal bleeding & 1 & 0 & 0 & 1 \\
$\quad$ Hematuria & 33 & 3 & 1 & 37 \\
$\quad$ Purpura & 25 & 15 & 6 & 46 \\
Total of bleeding & 58 & 18 & 7 & 83 \\
No bleeding & & & & \\
Total & & & & \\
\hline
\end{tabular}

Table 2, shows IPF and patients' diagnoses. IPF values ranged 0.5-59.6\% using Sysmex XN1000 (reference range 1-4.8\%). Decreased IPF were found in both the central group $(n=4)$ and peripheral group $(n=1)$. In the peripheral group, the majority of the patients $(n=24)$ showed increased IPF, oddly, it was also found increased in the central group $(n=25)$. IPF was found the highest in ITP patients (median 33.2\%) and the lowest in aplastic anemia patients (median 2.6\%). 
Table 2 Patients' diagnosis and IPF value

\begin{tabular}{|c|c|c|c|c|c|}
\hline Diagnosis & Mean \pm SD $(\%)$ & $\begin{array}{c}\text { Median } \\
\text { (Range) }(\%)\end{array}$ & $\begin{array}{c}\mathrm{IPF}<1 \% \\
\mathrm{n}(\%)\end{array}$ & $\begin{array}{c}\text { IPF } 1-4.8 \% \\
\mathrm{n}(\%)\end{array}$ & $\begin{array}{c}\mathrm{IPF}>4.8 \% \\
\mathrm{n}(\%)\end{array}$ \\
\hline ITP & $34.311 \pm 18.271$ & $33.2(2.3-59.6)$ & $0(0)$ & $1(1.20)$ & $8(9.63)$ \\
\hline Sepsis & $19.500 \pm 8.768$ & $19.5(13.3-25.7)$ & $0(0)$ & $0(0)$ & $2(2.40)$ \\
\hline Viral Infection & $13.850 \pm 9.319$ & $9.95(0.7-29.0)$ & $1(1.20)$ & $1(1.20)$ & $10(12.04)$ \\
\hline $\begin{array}{l}\text { Consumption } \\
\text { Coagulopathy }\end{array}$ & $8.266 \pm 4.500$ & $9.45(2.7-12.8)$ & $0(0)$ & $2(2.40)$ & $4(4.81)$ \\
\hline MDS & $7.564 \pm 7.825$ & $5.1(0.9-32.3)$ & $1(1.20)$ & $6(7.22)$ & $10(12.04)$ \\
\hline CML & $5.000 \pm 0.754$ & $4.9(4.3-5.8)$ & $0(0)$ & $1(1.20)$ & $2(2.40)$ \\
\hline ALL & $6.830 \pm 5.621$ & $4.45(2.0-19.9)$ & $0(0)$ & $5(6.02)$ & $5(6.02)$ \\
\hline AML & $10.455 \pm 13.215$ & $4.0(0.6-37.9)$ & $1(1.20)$ & $4(4.81)$ & $4(4.81)$ \\
\hline Multiple Myeloma & $3.150 \pm 0.494$ & $3.15(2.8-3.5)$ & $0(0)$ & $2(2.40)$ & $0(0)$ \\
\hline $\begin{array}{l}\text { Aplastic } \\
\text { Anemia }\end{array}$ & $6.500 \pm 9.322$ & $2.6(0.5-27.3)$ & $2(2.40)$ & $7(8.43)$ & $4(4.81)$ \\
\hline Total n (\%) & & & $5(6.02)$ & $29(34.93)$ & $49(59.03)$ \\
\hline
\end{tabular}

\section{Discussion}

In this study, it was found that patients with increased platelet consumption exhibiting a higher IPF median than the reduced thrombopoiesis patients. As expected, patients with infection would show an increased IPF, since the platelet activation from invasion results in adhesion of platelets to other immune cells or to thrombus formation, in turn leading to a consumptive state.[4] Increased IPF would also be expected in cases of ITP and consumption coagulopathy as a result of increased thrombopoiesis in response to platelet consumption.

In reduced platelet production patients the IPF is expected to be low. Reduced platelet production is due to megakaryocyte hypoplasia and ineffective thrombopoiesis. Megakaryocyte hypoplasia occurs due to a decrease megakaryocyte proliferation or bone marrow replacement by malignant cells or fibrosis.[5] Megakaryocyte hypoproliferation can occur because of damage to hematopoietic cells in the bone marrow caused by chemotherapy and radiotherapy. Chemotherapy and radiotherapy affect DNA so that it interferes cell division and maturation. Broad bone marrow suppression can involving erythrocyte series, leukocytes and platelets. After treatment, regeneration bone marrow runs slowly but it is often found that megakaryocytes is the last cell to undergo repair. Megakaryocyte hypoplasia occur due to bone marrow replacement by leukemia cell and malignant cell infiltration in cancer metastases or lymphomas hence, decreasing platelet count due to reduced megakaryocytes in the bone marrow.[6]

MDS was the most frequent etiology of thrombocytopenia in the current study and also is a frequent diagnosis made when thrombocytopenia occurs without obvious explanation in clinical practice. MDS is caused by different mechanisms: inhibition of megakaryocytic differentiation 
by suppressive cytokines, enhanced fasmediated apoptosis, or defective response to TPO.[7]

Some MDS patients also have inflammatory or immune systemic manifestations, which can explain the variability of IPF in MDS patients. A rather high IPF median of 5.1\% [0.9-32.3\%] was found in MDS patients and most of the reduced thrombopoiesis patients $(n=25)$ had increased IPF.

The oddly increased IPF in patients with reduced thrombopoiesis/malignancy was probably due to the limitation of BMP on those patients, thus, the diagnosis was not final/ confirmed. High IPF was also found in study by Adly et al, stating that it might be related to the sampling time as some of these patients may have pending recovery for their platelets counts. Strauss et al. reported that patients diagnosed with acute lymphocytic leukemia (ALL) also had elevated IPF\% (median $10 \%$ ), suggesting that thrombopoiesis is stimulated despite virtual absence of bone marrow progenitors. The increased IPF in reduced thrombopoiesis group was also reported by Cannavo [8] and Novita,[9] suggesting that the reduced thrombopoiesis patients were in infection state with IL-6 playing a role in megakaryocyte ploriferation and differentiaton, causing the increased IPF.[10]

\section{Conclusion}

Identifying the etiology of thrombocytopenia is important in treatment and management of the condition. IPF is decreased in patients with reduced thrombopiesis in the bone marrow and increased in cases with increased platelet consumption. The value is also affected by other mechanisms in the central thrombocytopenia, turning the value to elevate. Regardless, IPF is a promising tool in the diagnosis of thrombocytopenia, assisting clinicians to discriminate central and peripheral thrombocytopenia and it should be taken in consideration of routine laboratory examination in thrombocytopenic patients as it will have significant impact on the time taken to identify the underlying cause of thrombocytopenia and allow for effective treatment and management of thrombocytopenic patients.

\section{REFERENCES}

[1] P. Harrison, M.S.C. Robinson, I.J. Mackie, S.J. Machin, “ Reticulated platelets”, "Platelets Journal", vol.8, no.6, pp. 379-384.1997.

[2] I. Ali, C. Graham., N.C. Dempsey-Hibbert, "Immature platelet fraction as a useful marker in the etiological determination of thrombocytopenia", vol.78, no. pp.5661.2019.

[3] I. Pons, M. Monteagud, G. Lucchetti, GL. Muñoz, G. Perea, I. Colomina, J. Obiols, "Correlation between immature platelet fraction and reticulated platelets: Usefulness in the etiology diagnosis of thrombocytopenia", "European Journal of Haematology", vol. 85, no. 2, pp. 158-163.2010.

[4] K. Koyama, S. Katayama, T. Muronoi, K. Tonai, Y. Goto, T. Koinuma, J. Shima, S. Nunomiya, "Time course of immature platelet count and its relation to thrombocytopenia and mortality in patients with sepsis", "PLoS One Journal", vol.13, no.1, pp.1-16..2018. 
[5] M.L. Turgeon, Clinical Hematology Theory and Procedures 5th edition, Lippincott, Philadelphia 2012.

[6] B.A. O’Malley, Clinical Laboratory Hematology 2nd edition, Pearson, New Jersey. 2010.

[7] W. Li, K. Morrone, S. Kambhampati, B. Will, U. Steidl, A. Verma, "Thrombocytopenia in MDS: epidemiology, mechanisms, clinical consequences and novel therapeutic strategies', "Leukemia Journal", vol.30, no. 3, pp. 536-544. 2016.

[8] I. Cannavo, C. Ferrero, I. Sudaka, D. Aquaronne, F. Berthier, S. Raynaud, "Assessment of An Immature Platelet Fraction In The Diagnosis of Thrombocytopenia”, “Annales de Biologie Clinique”, vol. 68, no. 4, pp. 415- 420. 2010.

[9] A. Novita, "Nilai Rujukan Immature Platelet Fraction (IPF) Orang Dewasa di Jakarta Dengan XE-5000 Serta Aplikasi Klinis Pada Pasien Trombositopenia". [Online]. Available at : http://lib.ui.ac.id/file?file=pdf/abstrak20330041.pdf [Accessed: May, 20th, 2019].

[10] Gad ES, Salama AAA, El-Shafie MF, Arafa HMM, Abdelsalam RM\& Khattab M. The Anti-fibrotic and Anti-inflammatory Potential of Bone Marrow-Derived Mesenchymal Stem Cells and Nintedanib in Bleomycin-Induced Lung Fibrosis in Rats. Inflammation vol.43, pp:123-4. 2020 